\title{
THE IMPLEMENTATION OF GOOGLE CLASSROOM TO TEACH ENGLISH AT SMPN 2 NGRONGGOT IN PANDEMIC ERA COVID19
}

\author{
Handayani Eky Safitri, Erwin Hari Kurniawan
}

\begin{abstract}
The purpose of this study is to know how is the implementation of Google Classroom to teach English at SMPN 2 Ngronggot in pandemic era COVID 19 . Doing learning by using Google Classroom there are many advantages and disadvantages for all of the user excatly IX students at SMPN 2 Ngronggot.This study focused on four aspect. Teacher preparation, implementation of teaching, evaluation and the last students response. The reseacher use four instruments are interview, observation, documentation and students response. For preparation the teacher use lesson plan when she teach the students, for implementation the teacher also use English when she explain the material and sometimes the teacher use Indonesian because not all of the students understand what the teacher said to them, for evaluation the teacher give conclussion for material which them and sometimes the teacher give them homework and they must sumbit in Google Classroom and for the last students response some students still difficulty to use Google Classroom because they think this is new learning.The result of this research is implementation by using Goggle Classroom can be the first method to teach online learning at SMPN 2 Ngronggot and this research also reccomended for, first the students as the students should have motivation although there are many obstacless using Google Classroom one of it is limit in access internet, the handphone is broke or did not have mobile phone but the student must try to join with their friend in order to all of the material can be known, for the teacher should give another ways in order the all of students can follow the material and for next the readers teaching by using Google Classroom can be motivate to others.
\end{abstract}

Keywords: teaching English,Google Classroom,and pandemic era COVID 19.

\section{INTRODUCTION}

In this globalization era techonology can make students control their learning and also more engaged in class the learning process has an important role as an effort to improve the quality of education. In order to create learning meaningful, of course, must optimize more learning direct at modernization activities.One of the problems facing the world of education today is the impact of the COVID-19 pandemic which is now starting to spread to the world education, so that the government tries to dismiss all educational institution besides that the government also limits activities man outside the home attempts to limit the interaction between many people things it aims to break the chain of spreading COVID-19.This policy does not only apply in the country of Indonesia, but also 
in countries that have been exposed to COVID-19. As is the policy then the school implements teaching and learning activities from a distance or online learning (online). Implementation The distance learning process in the era of the COVID-19 pandemic is a demand for teachers to select and use appropriate methods for the learning process teaching continues in other words, it creates educational interactions. The application of online learning certainly demands readiness for both parties, both from education personnel (teachers) and from students. After all, online learning is in dire need qualified technology assistance so that it can be accessed so that it can facilitate the learning process.

Teaching English has been an important issue in countries where English is not their first language, so learning second language is difficult for learners because they can not speak English in real life situation, because they should learn sentence in textbooks not in real environment. Therefore, teachers should always look for useful strategies to reduce the difficulty of teaching English language (Long,1996; Chen, 2007; Nuun, 2011) and they have to deal with many challenges and often have question about the best ways to teach. Teaching English plays an important role in position and success as foreign language. Students generally find only a small amount of English inside and outside the classroom, or as a communication tool during social interaction. This absence places great responsibility on English teacher to ensure students learn English in supportive environment and bring successful language learning into classroom. Thus the language knowledge of teachers and teaching skills along with al host of other complex skills is important in teaching English as foreign language.

Google Classroom now became one of online learning to teach the students not only in one lesson but more than one lesson the reason use it because the condition now is different like usual. In this study descibed about the implementation using Google Classroom to teach English at SMPN 2 Ngronggot in pandemic era COVID 19 acctually IX class. According to Miarso (2004) the development of science and technology is one of the products of an educate human being, and in turn humans need to be deeper and able to take benefits and not fall victim to the development of science and technology alone. Explore and take advantage of the development of science and technology is not possible for all people and time demanding increasingly sharp specialization. The development of information and technology is very important remember every year or even every month science and information is always developing. With an increasingly technological era this development is expected to be a learning program make good use of technology. According to Cox (2009) the implementation of Google Classroom actually in school is needed because it can help students to prepare for the future and as we are in the digital era which makes us should know how to use it properly. But Bill and Melinda Gates Foundation, 93\% of teachers already use digital tools in Google Classroom which means there are still teachers who do not use digital tools. Thus, we get the conclusion that technology is useful for learning process. There are a lot of online social learning environment and educational tools which are accessible for both students and teachers, such as, Google Docs, Google Scholar, and Google+. Google launched an e-learning tool named Google Classroom. Google Classroom is a blended 
learning platform with interesting and simple features for schools. Only institution's database can invite students to classrooms. Google classroom can help to manage paperless system.

Based on explanation above, the researcher research about the implementation of Google Classroom to teach English at SMPN 2 Ngronggot in pandemic era COVID 19. The researcher use that title because at SMPN 2 Ngronggot use Goole Classroom doing the online learning, it is still new for the students because sometimes learning doing directly face to face but now online the condition force it to do it.

\section{METHOD}

This research uses desccriptive qualitative research method because it to describe the implementation of Google Classroom to teach English at SMPN 2 Ngronggot in pandemic era COVID 19. According to Moelong (2001) that qualitative research will find the descriptive data that is words, words orally or witten by the subject and their attitude is be researched.

Data Analysis is so that what is done by working, with data, organizing data, sorting it out into unit that can be managed, synthesize it, find and determine patterns, find what's important and what's learned, and decides what is told to others (Moelong, 2011). Analysis of qualitative data is inductive, which is an analysis based on the data obtained, then developed int hypothesis. Based on the hypothesis formulated based on data these, then are sought again repeatedly sorth it can be concluded whether the hypothesis is accepted or rejected based on data collected. If based on data that can be collected repeatedly with triangulation techniques, it turns out the hypothesis is accepted, then the hypothesis develops into a theory (Sugiyono, 2016). Data analysis in this study used data analysis flow model by Miles and Huberman. In detail in the process data analysis is described as follows: (Source: Sugiyono, 2016). There are several steps in data analysis as follows:

1. Data Reduction: The data obtained from the field is sufficient many, for that it should be noted carefully and in detail. As has been stated, the longer the researcher is to field, then the amount of data is getting more and more complex and complicated. For this reason, it is necessary to immediately carry out analysis and data through reduction data. Reducing data means summarizing, selecting things that are the subject focuses on things that are important, looking for themes and the pattern. Thus the data that has been reduced will be provides a clearer picture, and makes it easier researchers to collect further data, and search for it if needed. Data reduction can be assisted by tools electronics is like a minicomputer, by providing aspects certain (Sugiyono, 2016). The data can be obtained from interview, observation, questionnaire and documentation are reduced by summarizing, choosing important information and classifying it based on focus. In this study the deducted data is the result of interview, observation, questionnaire and documentation are implementation of Google Classroom as teaching English. So the data is clearly and briefly so that all part of the focus investigated is easy to understand. 
2. Data Display (Presentation of Data): after the data is reduced, the next step is display data. The presentation can be done in the form of a description briefly, charts between categories, flowcharts and the like. In terms of this is Miles and Huberman (1984) "the most frequent form of display data for qualitative research data in the past has been narrative text ". The most frequently used to present data in Qualitative research is a narrative text (Sugiyono, 2016). Presentation of data obtained in interviews, observation, questionnaire and documentation as supporting data are lesson plan and student assessment.

3. Conclusion Drawing / Verification: the third step in qualitative data analysis according to Miles and Huberman are inference and verification. The initial conclusions expressed are still in character temporary, and will change if no evidence is found support at the data collection stage next. But if the conclusions are put forward at that stage preliminary, supported by current valid and consistent evidence researchers return to the field to collect data, then the conclusions put forward are conclusions credible (Sugiyono, 2016).

From explanation above the researcher makes conclusion from the data display. In short, the steps in analysing the data are: (1) the researcher collects the data through interview and questionnaire. Then, the researcher selects, identify, and focuses on the data by referring to formulation of the research problem. (2) After selecting the data, the researcher displays those data into good sentences. (3) After displaying data, the conclusion is drawn. Moreover, to get validity of data, the interview is supported by questionnaire, observation and documentation

1. Data validity. That research results can be accounted for needed to check the validity of the data presented is valid or not, then the data validity technique is needed (Moelong, 2008). Masganti (2016) The validity of qualitative research can be built with 4 (four) characteristics in the study namely, credibility, transferability, dependability (dependency), confirmability (certainty).

2. Credibility. In qualitative research, researchers go into the field and participate and in the research subjects, the participation not only done in a short time, however take longer than just to see and knowing the research subject. by extending the following This inclusion means that researchers stay in the field of research up to data collected is full. Extension of participation researchers can test the truth of the information obtained. The explanation is as bellow:

a. Perseverance in observing, that is for direct experience is a powerful tool for testing truth, technique observation also allows seeing an observing itself, then records behaviour and events as they are in fact. From explanation above researcher must also read various refences to open up the researchers insight so that researcher can examine the data found.

b. Triangulation is a technique for measuring validity data in the context of certainty checking or comparison against that data. triangulation is done to obtain valid and valid data. In this study researchers using triangulation of sources that is by the way comparing observational data with results interview, and also compare the results of the interview with other interview. From above can conclude that validity of data get from teacher English, the headmaster and the IX students of SMPN 2 Ngronggot. 
3. Transferability. To achieve the development of the results of this study then researcher can do the following things:

a. Collect data in detail so that it is possible make comparisons in other contexts so the diversity of research results can be applied to other situations.

b. Develop detailed data descriptions to guarantee compatibility of other possible research results.

c. For applying the results of research that has been obtained, the researcher can make a report and give a clear description, systematic and trustworthy.

d. Thus the reader it becomes clearer the results of research that have been obtained so they can decide whether or not the results of research applied elsewhere (Masganti, 2016). From above the reader will understand the result of the research, because it provides a detailed, clear, and systematic and also reliable description.

4. Dependability. To obtain data relevant to research then the researcher can take the following steps:

a. Use various methods to collect data to cover up the weaknesses of each method, for example conduct interviews with students to help researchers' understanding of observational results about behaviour student.

b. Establish an audit trail. This process can done by involving an auditor maybe a critical friend, boss or expert to test data collection, analysis and interpretation process (Masganti,2016). The must be an advisor in the research.

5. Confirmability. There are two steps you can take to guarantee whether the results of research can be proven where research results in accordance with the data collected and included in the field report, namely: practicing triangulation is by using various methods data collection methods and cross-checking data and reflecting. This method is to keep a daily journal in research conducted (Masganti, 2016).The researcher should prepare interview frame work, questions and questionnaire which deliver into the headmaster, teacher and the students IX class of SMPN 2 Ngronggot.

\section{RESULT AND DISCCUSSION}

The researcher to know the implementation of Google Classroom to teach English at SMPN 2 Ngronggot in pandemic era COVID 19 and the result are:

1. For teacher preparation the teacher have lesson suitable with the curriculum now in this school that is K13 and use one sheet. The teacher use lesson plan in order to not deviate in learning objective and the teacher chose the media wich suitable with the material. The teacher make it because make the teacher easier in her delivered the material. Sometimes the teacher use personal chat or in Microsoft sway then given quiz in Microsoft form then when the explanation the lesson the teacher record it with the OBBS. Bandicam or XRECORDER then the result of video her shared on her group the goal is to announced to the students if not only learning by using Google Classroom. 
2. The implementation is not good because some students not have mobile phone and some students sometimes not understand about the material in Google Classroom the knowledge of the students still less and they did not understand how to use Google Classroom. The students more think play than study. Delivered the material by using Google Classroom was not make the students understand although they can discussed their material in there because there is "forum kelas" they can asked to the students if they did not understand about the material but the students still not understand how to use it. If from school shift it is mean that with level. They can go to school and the teacher told to the students how to using Goggle Classroom in learning the teacher can taught the students how to join in Google Classroom and the teacher not forget to given motivation to the students and told to the students if there is no difference between online and offline in learning. The teacher had remind the students and not forget to given them motivation in order to the students fight to follow the learning in Google Classroom the goal of given motivation in order to the students not lazy to follow the learning at Google Classroom. Media and technique when the teacher used in learning was variation, because to made the students not bored with the lesson and made the students interested in learning also made the students more understood when the teacher explained in Google Classroom. The teacher combine with other media like Microsoft form, Microsoft sway, Google form in order to add the knowledge of the students and helped the students if now globalization era so must known everything not only fame but also learning like this and then they can told to the other person who did not about this media.

3. The evaluation in the result still not good because many obstacles in using Google Classroom and the quota of the students not enough because sometimes the students not bough the quota so this is some obstacles from the students. Sometimes the students active but sometimes not active in Google Classroom because the initiate the students difference and the motivation of students can from their selves and student still less in knowledge for new application like Google Classroom. The students ask to fill the absent which given by the teacher also must follow the learning and submit the duty. Quiz or UH who delivered by the teacher so the students though if they must have responsibility one by one. Because some obstacles so the students less in discipline when follow the learning by using Google Classroom. And there is no monitoring from the parents so the students did something else like playing game and others. Still not effective because $i$ this village the economic of the students is average middle down. And the students not too interest on online learning like Google Classroom because they have many reason not join it the teacher also given alternative ways to know the announcement like WhatsApp easy and effective in delivered the material or duty efficient in time, can see every time. Because not everyday we have quota so the online learning is helped than offline we can see the duty whenever we need and automatically save in Google Drive. Score not only in the Google Classroom but also from UH and Microsoft form. And the score it can be got from their daily activity, their duties and their attitude with the teacher. 
4. Students Response to know about students responses about the implementation of Google Classroom As Teaching E-Learning Media at SMPN 2 Ngronggot In Pandemic Era Covid 19 researcher used questionnaire. The researcher done research in the ninth grade. There are 75 students in that class, then in A class there are 32 students, in B class there are 22 students and 21 for $\mathrm{C}$ class. The researcher done collecting the data of questionnaire by giving the questionnaire in the class group of WhatsApp. That was done because of COVID-19 virus, we must do social distancing.

\section{CONCLUSSION}

The conclussion for explanation above are the teacher preparation good because the teacher bring lesson plan and the lesson suitable with the lesson plan but sometimes the teacher use Indonesian to explain the lesson. And the students have obstacles so the response is still less and the teacher taught be patiently in order to made the students about the lesson which explained in Google Classroom for evaluation still less and the students not too interested using Google Classroom as learning. But on the post teaching the teacher gave the task on their book the task must submit in Google Classroom. But not all of the students submit it in Google Classroom some of them submit on WhatsApp. in the result of students response still less in learning by using Google Classroom because the students who join in group only a half of all of students. They did not interest in using Google Classroom because not all of them have mobile phone, so they the join with their friend and they have group on WhatsApp. Some of the students though that using WhatsApp is more effective than other application in learning.

\section{REFERENCES}

Cox, J. (2009). teachhub. (http://www.teachhub.com/benefits-technologyclassroom, Retrieved from teachhub).

Masganti. (2016). Metode Penelitian Pendidikan Islam, Medan: IAIN press.

Miarso, Yusuf H. (2004). Menyemai Benih Teknologi Pendidikani. Jakarta: Kencana Prenada Media Group.

Moelong, L. J. (2008). Metodologi Penelitian Kualitatif (Edisi Revisi). Bandung: PT Remaja Rosdakarya.

Sugiyono. (2012). Metode Penelitian Kuantitatif Kualitatif dan R\&D. Bandung: Alfabeta. 